\title{
PENTINGNYA APD (ALAT PELINDUNG DIRI) SEBAGAI UPAYA PENCEGAHAN PENYAKIT AKIBAT KERJA PADA PERAWAT DI RS
}

\author{
Esty Purnama Sari
}

\section{Estypurnamasari97@gmail.com}

\section{Latar Belakang}

Rumah sakit tidak hanya menjadi tempat pengobatan, tetapi juga sebagai sarana pelayanan kesehatan yang dapat menjadi sumber infeksi bagi orang lain termasuk perawat dan tenaga medis lainnya (Septiari, 2012). Perawat merupakan petugas kesehatan terbanyak dengan komposisi hampir 60\% dari seluruh petugas kesehatan lainnya dirumah sakit dan salah satu profesi yang sering terkena penyakit akibat kerja (Sudarmo, 2016).

Melihat tingginya resiko terhadap gangguan kesehatan di rumah sakit, maka perlu di lakukan upaya-upaya pencegahan terhadap kejadian penyakit atau traumatic akibat lingkungan kerja dan faktor manusianya. Salah satu di dantaranya adalah menggunakan APD. Perawat bertanggung jawab menjaga keselamatan klien di rumah sakit melalui pencegahan kecelakaan., cidera, trauma dan melalui penyebaran infeksi di unit perawatan intensif hal ini sering menyebabkan perawat kurang memperhatikan teknik aseptic dalam melakukan tindakan keperawatan (Potter, 2005)

Alat pelindung diri (APD) merupakan suatu alat yang di pakai untuk melindungi diri atau tubuh terhadap bahaya-bahaya kecelakaan kerja (perawat), dimana secara teknis dapat mengurangi tingkat keparahan dari kecelakaan kerja yang terjadi pada perawat atau pasien.alat pelindung diri tidak menghilangkan atau pun mengurangi bahaya yang ada. Alat pelindung diri ini hanya mengurangi jumlah kontak dengan bahaya yang dengan cara penempatan penghalang antara tenaga kerja dengan bahaya yang ada pada pasien dan bahkan sebaliknya (Suma'mur. 2009). Perawat diwajibkan untuk menggunakan APD untuk menghindari resiko keselamatan dan kasehatan kerja di rumah sakit dalam memberikan asuhan keperawatan. Perawat dalam 
menjalankan peran sebagai pemberi asuhan keperawatan dituntut untuk menjaga keselamatan diri dari bahaya serta dampak yang ditimbulkan yakni dengan menggunakan proteksi diri, dimana proteksi diri merupakan suatu pencegahan untuk menghindari atau meminimalkan bahaya (Diklat RS dr. Kariadi, 2003 dalam Sarce 2009).

Penelitian ini bertujuan untuk menganalisis peran dan pentingnya pengguanaan APD ( Alat Pelindung Diri ) sebagai upaya pencegahan penyakit akibat kerja pada perawat di Rumah Sakit.

Kata Kunci : Alat Pelindung Diri (APD), Upaya Pencegahan Penyakit, Penyakit Akibat Kerja (PAK) di RS

\section{Metode}

Metode yang digunakan yaitu literature review, yaitu dengan menganalisis buku-buku dan jurnal online yang berkaitan dengan pentingnya APD (Alat Pelindung Diri) sebagai upaya pencegahan penyakit akibat kerja pada perawat di Rumah Sakit. Dalam Penulisan Jurnal ini diawali dengan pemilihan topik, kemudian menuliskan kata kunci berupa " Alat Pelindung Diri (APD), "Upaya Pencegahan Penyakit", dan "Penyakit Akibat Kerja di RS”. Dari hasil pencarian jurnal online kemudian diolah dan dianalisis sehingga menghasilkan sebuah pembahasan dan kesimpulan dari topik yang ditetapkan. Sumber penelitian ini berasal dari beberapa literature jurnal. Jurnal ini dibatasi dengan tahun paling tua 2012. Jumlah referensi jurnal yang digunakan sebanyak 12 referensi jurnal. Berdasarkan tujuan penelitian, maka penelitian ini merupakan penelitian eksplorasi untuk mengetahui mengenai peran dan pentingnya pengguanaan APD ( Alat Pelindung Diri ) sebagai upaya pencegahan penyakit akibat kerja pada perawat di Rumah Sakit.

\section{Hasil}

Penggunaan APD di RS di Indonesia ternyata lebih dari 40\%, dan kenyataan di lapangan para perawat rata-rata hanya menggunakan salah satu APD (jas lab, sarung tangan, atau masker saja) saat menangani pasien. Adapun alasan perawat tidak menggunakan APD ketika menangani 
pasien, pada umumnya (52\%) di rumah sakit tidak tersedia APD yang lengkap. Tidak tersedianya APD di rumah sakit kemungkinan di sebabkan karena kurangnya perhatian dari kepala ruang dalam penyediaan APD, atau anggaran rumah sakit yang terbatas sehingga dana untuk pengadaan APD juga menjadi terbatas. Alasan lain perawat karena malas, lupa, tidak terbiasa dan repot. Alasan-alasan tersebut sangat terkait dengan kesadaran/perilaku perawat dalam penggunaan APD. Penyebab utamanya kemungkinan karena kurangnya pemahaman perawat terhadap bahaya yang akan timbul sebagai akibat dari adanya penyakit yang berbahaya (Sukarjo, 2012, p. 23).

Penggunaan Alat Pelindung Diri (APD) pada perawat masih dikategorikan kurang dalam pelaksanaan dan penerapannya. Hal ini menunjukkan bahwa sikap perawat dalam penggunaan Alat Pelindung Diri (APD) masih kurang, ditunjukkan dengan sikap negatif sebanyak 53,30\%. Menunjukkan perilaku penggunaan Alat Pelindung Diri (APD) perawat tidak signifikan yang ditunjukkan dengan mayoritas responden yang memiliki perilaku penggunaan Alat Pelindung Diri (APD) yang kurang patuh berjumlah 44 perawat (52,4\%) (Zubaidah, 2015)

Penelitian (Parsinahingsih dan Supratman,2008) di RSUD Moewardi Solo mengidentifikasikan: penggunaan APD yang kurang sempurna pada perawat $20 \%$ dan perawat yang tidak memakai APD 9\%.

Penelitian (Pascaningrum, 2011) di RSUD Haji Jakarta mengidentifikasikan 39,1\% perawat tidak menggunakan APD saat melakukan tindakan.

Penelitian yang dilakukan ( Zaki, M., dkk, 2018) di Rumah Sakit Umum Daerah Dr. RM. Pratomo Bagansiapiapi khusus pada tenaga kesehatan perawat masih terdapat beberapa orang perawat saat dalam penanganan pasien tidak menggunakan APD seperti masker dan handscun. Adapun alasan perawat yaitu ingin buru-buru/ cepat, terkadang mengganggu/ tidak aman, risih dan tidak ada sanksi jika tidak menggunakan Alat Pelindung Diri atau tidak ada sanksi yang berupa tertulis dan atau cuma berupa teguran dari kepala ruangan. 


\section{Pembahasan}

Rumah sakit adalah dibidang pelayanan kesehatan yang tujuan utamanya memberikan pelayananterhadap masyarakat yang terkena penyakit, sebagai usaha meningkatkan derajat kesehatan yang setinggi-tingginya. Dalam setiap proses pelayanan kesehatan di rumah sakit, terlihat adanya faktor-faktor penting sebagai pendukung pelayanan itu sendiri, yang selalu berkaitan satu dengan yang lainnya. Faktot-faktor tersebut meliputi pasien, tenaga kerja kesehatan, lingkungan kerja rumah sakit, cara melakuka pekerjaan serta proses pelayanan kesehatan itu sendiri di samping memberikan dampak positif fakor tersebut juga memberikan nilai negatif terhadap semua komponen yang terlibat dalam proses pelayanan kesehatan lainnya yang berakhir dengan timbulnya kerugian seperti tidak menggunakan APD (Pustilbang ILM FK, UGM 2000).

Perawat merupakan petugas kesehatan terbanyak dengan komposisi hampir $60 \%$ dari seluruh petugas kesehatan lainnya dirumah sakit dan salah satu profesi yang sering terkena penyakit akibat kerja (Sudarmo, 2016). Perawat berisiko terkontaminasi dengan penyakit apabila selama melakukan interaksi dengan pasien tidak memperahtikan tindakan pencegahan (universal precaution) dengan menggunakan Alat Pelindung Diri (APD) seperti sarung tangan, masker, kacamata, gaun (Riyanto, 2011). APD sangat penting dipakai oleh perawat dalam melaksanakan tugas, dan memiliki dua fungsi yaitu untuk kepentingan perawat sekaligus untuk kepentingan petugas itu sendiri (Yulita dkk, 2014).

Alat pelindung diri (APD) merupakan suatu alat yang di pakai untuk melindungi diri atau tubuh terhadap bahaya-bahaya kecelakaan kerja (perwat), dimana secara teknis dapat mengurangi tingkat keparahan dari kecelakaan kerja yang terjadi pada perawat atau pasien.alat pelindung diri tidak menghilangkan atau pun mengurangi bahaya yang ada. Alat pelindung diri ini hanya mengurangi jumlah kontak dengan bahaya yang dengan cara penempatan penghalang antara tenaga kerja dengan bahaya yang ada pada pasien dan bahkan sebaliknya (Suma'mur. 2009). 
Melihat tingginya resiko terhadap gangguan kesehatan di rumah sakit, maka perlu di lakukan upaya-upaya pencegahan terhadap kejadian penyakit atau traumatic akibat lingkungan kerja dan faktor manusianya. Salah satu di dantaranya adalah menggunakan APD. Perawat bertanggung jawab menjaga keselamatan klien di rumah sakit melalui pencegahan kecelakaan., cidera, trauma dan melalui penyebaran infeksi di unit perawatan intensif hal ini sering menyebabkan perawat kurang memperhatikan teknik aseptic dalam melakukan tindakan keperawatan (Potter, 2005).

Menurut WHO (2005, hlm.24-25) Alat Pelindung Diri (APD) yang dapat digunakan untuk mencegah terjadinya kontaminasi meliputi penggunaan sarung tangan, kaca mata pelindung, masker, apron, gown, sepatu, dan penutup kepala. Pemakaian APD merupakan upaya untuk menciptakan kesehatan dan keselamatan kerja yang optimal. Perilaku perawat dalam menggunakan APD merupakan salah satu faktor penentu penerapan penggunaan APD di rumah sakit.

Penggunaan Alat Pelindung Diri (APD) sangat penting untuk melindungi mukosa - mulut, hidung dan mata dari tetesan dan cairan yang terkontaminasi. Mengingat bahwa tangan dikenal untuk mengirimkan patogen ke bagian lain dari tubuh ataupun individu lainnya. Kebersihan tangan dan sarung tangan sangat penting baik untuk melindungi pekerja kesehatan dan untuk mencegah penularan kepada orang lain. Penutup wajah, pelindung kaki, gaun atau baju, dan penutup kepala yang juga dianggap pentinguntuk mencegah penularan ke petugas kesehatan World Health Organization (WHO) (Arifianto, 2017).

Alat Pelindung Diri (APD) sangat penting untuk dipakai oleh seorang perawat dalam melaksanakan tugas. APD ini digunakan oleh petugas memiliki dua fungsi yaitu untuk kepentingan penderita dan sekaligus untuk kepentingan petugas itu sendiri. Perlengkapan pelindung diri dalam praktek kesehariannya lebih banyak berfungsi sebagai "pelindung penderita" daripada sebagai "pelindung petugas". Melindungi penderita dari kemungkinan terjadinya infeksi mikroba merupakan tugas pokok yang dimulai saat penderita masuk rumah sakit untuk menjalani prosedur tindakan medis serta asuhan keperawatan sampai tiba saatnya penderita keluar dari rumah sakit (Darmadi, 2008, hlm.88). 
Pemberian APD pada tenaga kerja keperawatan, merupakan upaya terakhir pada perawat dan cara kerja yang aman (work practices) telah maksimum dilakukan. Oleh karena itu perawat harus benar-benar di terapkan dalam penggunaan APD di suatu rumah sakit dimana di dalamnya tenaga kesehatan melakukan pekerjaan dengan baik. Hal ini dilakukan karena perawat adalah faktor yang paling penting dalam suatu penggunaan APD. Perawat sebagai tenaga kesehatan yang dapat menimbulkan infeksi yang berdampak keparahan bahkan sampai meninggal. (Boedi Maryoto, 1997)

Menurut Geller (2001) kepatuhan pelaksanaan standar operasional prosedur penggunaan APD masih rendah disebabkan karena budaya keselamatan yang belum cipta dalam lingkungan kerja. Budaya keselamatan dipengaruhi oleh faktor perilaku,faktor lingkungan dan faktor orang. Keberhasilan upaya pencegahan infeksi yang dilakukan oleh perawat bedah salah satunya penggunaan APD yang wajib dipakai selama berada di kamar operasi, yang tujuannya tidak hanya untuk perlindungan petugas itu sendiri dalam melakukan tindakan yang aman tetapi juga untuk keselamatan pasien. Keberhasilan ini sangat dipengaruhi oleh ketaatan individu pada aturan yang berlaku atau kepatuhan. Upaya pencegahan infeksi yang dilakukan oleh perawat bedah salah satunya dengan penggunaan APD yang wajib dipakai ketika mereka bekerja di kamar operasi. Selain itu, ketidakpatuhan perawat dalam penggunaan APD ini seperti tidak menggunakan handscoon atau masker, atau bahkan keduanya saat melakukan tindakan keperawatan, misalnya pemasangan infus dan pemberian obat suntik dengan alasan lupa ataupun merasa kesulitan dan tidak nyaman saat melakukannya. Bahkan akibat dari ketidakpatuhan perawat dalam penggunaan APD telah terjadi kecelakaan seorang perawat tertusuk jarum suntik bekas pasien dan setelah dilakukan pemeriksaan laboratorium akhirnya perawat tersebut dinyatakan tertular penyakit Hepatitis-B.

Berdasarkan teori Domino, penyebab pekerja tidak menggunakan Alat Pelindung Diri (APD) yaitu melalui hubungan mata rantai sebab akibat dari beberapa faktor penyebab tersebut adalah lemahnya manajemen dan pengawasannya, sanksi, kurangnya sarana dan prasarana, kecerobohan atau kelalaian dari manusia, serta tindakkan manusia yang tidak aman (Buntarto, 2015). 
Frank menjelaskan, penyebab Penyakit Akibat Kerja (PAK) dan kecelakaan kerja disebabkan oleh manajemen kurang kontrol.Reason mengatakan orang tidak menggunakan Alat Pelindung Diri (APD) diri dikarenakan kurang pengetahuan atau keterampilanya , disebabkan kurangnya pelatihan, prosedur atau peraturan mengenai keselamatan kerja. Penyebab kecelakaan kerja adalah ketimpangan manajemen sehingga memperlihatkan pengaruh manajemen dalam mengakibatkan terjadinya kecelakaan kerja. (Djatmiko, 2016).

\section{Penutup}

Rumah sakit tidak hanya menjadi tempat pengobatan, tetapi juga sebagai sarana pelayanan kesehatan yang dapat menjadi sumber infeksi bagi orang lain termasuk perawat dan tenaga medis lainnya (Septiari, 2012). Perawat merupakan petugas kesehatan terbanyak dengan komposisi hampir 60\% dari seluruh petugas kesehatan lainnya dirumah sakit dan salah satu profesi yang sering terkena penyakit akibat kerja (Sudarmo, 2016). Melihat tingginya resiko terhadap gangguan kesehatan di rumah sakit, maka perlu di lakukan upaya-upaya pencegahan terhadap kejadian penyakit atau traumatic akibat lingkungan kerja dan faktor manusianya. Salah satu di dantaranya adalah menggunakan APD. APD sangat penting dipakai oleh perawat dalam melaksanakan tugas, dan memiliki dua fungsi yaitu untuk kepentingan perawat sekaligus untuk kepentingan petugas itu sendiri (Yulita dkk, 2014).

Saran

Bagi Rumah sakit : Kepala ruang memberikan sanksi yang tegas bagi perawat yang tidak menggunakan Alat Pelindung Diri (APD) pada saat melakukan tindakan. Perlu diadakannya pelatihan secara berkala mengenai penggunaan Alat Pelindung Diri, serta memastikan seluruh perawat mengetahui dan memahami seluruh informasi yang didapatkan dari pelatihan tersebut dengan mengadakan pre-test dan post-test.

Bagi Penelitian Selanjutnya : disarankan agar sumber yang digunakan dalam penelitian lebih luas, sehingga hasil penelitian lebih maksimal. 


\section{Daftar Pustaka}

1). Iriani, R. (2018). Hubungan Pendidikan, Pengetahuan, Dan Masa Kerja Dengan Tingkat Kepatuhan Perawat Dalam Penggunaan APD Di RS Harum Sisma Medika Tahun 2019. Jurnal Persada Husada Indonesia, 6 (20) 21-27

2). Istih, S, M, P., Joko, W., Erlisa, C. (2017). Hubungan Unsafe Action dengan Kecelakaan Kerja Pada Perawat di Rumah Sakit Panti Waluya Malang. Nursing News, 2 (2)

3). Muchlis, S., Muhammad, Y. (2017). Kesadaran Perawat Dalam Penggunaan Alat Pelindung Diri (APD). Jurnal Ilmiah Mahasiswa Keperawatan, 2 (3)

4). Putri, S, A., Bagoes, W., Zahroh, S. (2018). Faktor- Faktor Yang Berhubungan Dengan Tingkat Kepatuhan Perawat Terhadap Penggunaan Alat Pelindung Diri (APD) Di RSUP DR. Kariadi Semarang (Studi Di Instalasi Rawat Inap Merak). Jurnal Kesehatan Masyarakat (eJournal),6(1)

5). Putri, S., Santoso., Endang, P, R. (2018). Pelaksanaan Dan Keselamatan Dan Kesehatan Kerja Terhadap Kejadian Kecelakaan Kerja Perawat Rumah Sakit. Jurnal Endurance 3(2) (271277)

6). Sari, R, Y., Erni, S., Achmad, S. (2014). Pengaruh Sosialisasi SOP APD Dengan Perilaku Perawat Dalam Pengguanaan APD ( Handscoon, masker, gown) Di RSUD Dr. H. Soewondo. Karya Ilmiah

7). Sawy, S, F., Elly, W. (2019). Faktor - Faktor Yang Mempengaruhi Motivasi Perawat Dalam Penggunaan Alat Pelindung Diri (APD) Di Rumah Sakit. JIM FKEP, IV (1)

8). Simamora, R. H. (2020). Pelatihan Komunikasi Efektif untuk Meningkatkan Efikasi diri Perawat dalam Pelaksanaan Identifikasi Pasien. JURNAL ILMIAH KESEHATAN MASYARAKAT: Media Komunikasi Komunitas Kesehatan Masyarakat, 12(1), 49-54. 
9). Simamora, R. H. (2011). ROLE CONFLICT OF NURSE RELATIONSHIP WITH PERFORMANCE IN THE EMERGENCY UNIT OF HOSPITALS RSD DR. SOEBANDI JEMBER. The Malaysian Journal of Nursing, 3(2), 23-32.

10). Sitorus, E, D., Asnah, S. (2016). Tingkat Kepatuhan Perawat Mengenai SOP Dalam Pengguanaan APD Di Ruang Rawat Bedah LT.12 Blok.D RSUD Koja Jakarta Utara Tahun 2016. Jurnal Akademi Keperawatan Husada Karya Jaya, 2 (2)

11). Sudarmo., Zairin, N,H., Lenie, M. (2016). Faktor Yang Mempengaruhi Perilaku Terhadap Kepatuhan Penggunaan Alat Pelindung Diri (APD) Untuk Pencegahan Penyakit Akibat Kerja. Jurnal Berkala Kesehatan, 1 (2).

12). Zaki , M., Agnes, F., Dian, M, S, S. (2018). Faktor- Faktor Yang Memengaruhi Pengguanaan Alat Pelindung Diri (APD) Tenaga Kesehatan Perawat Di RSUD DR.RM.Pratomo Bagansiapiapi Kabupaten Rokan Hilir. Excellent Midwifery Journal, 1 (2). 